\title{
La (no) metáfora del cuerpo. Cuerpo abusado, cuerpo torturado, cuerpo transfigurado*
}

\author{
Pedro Pablo Achondo Moya ${ }^{a}$
}

Pontificia Universidad Católica de Valparaíso, Chile

https://orcid.org/0000-0002-1247-5412

RECIBIDO: 22-06-19. APROBADO: 22-10-19

Resumen: El artículo indaga en la temática del cuerpo a partir de la experiencia del sufrimiento humano: dimensión que supera cualquier escrito y muchas veces fractura las aproximaciones discursivas y teóricas. Sin embargo es menester asumir el riesgo con vistas a la esperanza. Por eso se ha profundizado en el padecimiento ligado al abuso y la tortura, entendiendo al cuerpo como lugar "sin metáforas" donde se alberga la memoria, la resistencia y una esperanza que va más allá de lo meramente racional. El cuerpo, en cuanto exceso de significado, es también un territorio y una membrana en donde se acoge o rechaza al otro. Desde ahí la teología y la ética son desafiadas a repensar la realidad corporal en la perspectiva de una verdadera compasión, confianza y lenguaje que den cuenta de la complejidad del cuerpo maltratado. La actualidad eclesial y social han puesto en tela de juicio prácticas y discursos sobre el cuerpo sufriente. El abuso sexual, de poder y conciencia se han manifestado como realidades que están lejos de ser marginales. A partir de una lectura fenomenológica nos preguntamos por la posibilidad de continuar viviendo -y creyendo- luego de haber padecido lo indecible. Para ello se estudian algunos casos y se lleva a cabo un agudo análisis bibliográfico según el cual se pueden descubrir nuevos rasgos del ser humano y de Cristo, en cuanto Mesías que llora y consuela. La esperanza cristiana de cara al Dios-en-la-carne crucificado puede permitir a los cuerpos que padecen volver a ponerse de pie. Este artículo busca afirmar esto asumiendo la radical dificultad que el sufrimiento impone, para el pensar, el decir y el continuar la vida.

Palabras Clave: Cuerpo; abuso; tortura; territorio; piel; perversión; sufrimiento; esperanza; lágrimas.

*Artículo de reflexión

${ }^{a}$ Autor de correspondencia. Correo electrónico: pedro.achondo@pucv.cl 


\section{The (not) Metaphor of the Body. Abused Body, Tortured Body, Transfigured Body}

AвSTRACT: The article investigates the subject of the body from the experience of human suffering. Suffering constitutes a dimension that surpasses any writing about it and fractures discursive and theoretical approaches. However, it is essential to take the risk in view of hope. For this reason, this text inquires about the suffering caused by abuse and torture. We understand the body as a place free of metaphors, a place where memory, resistance and hope go beyond a rational approach. The body, as an excess of meaning, is also a territory and a membrane where the other is welcomed or rejected. Therefore, theology and ethics are challenged to rethink bodily reality in the face of true compassion. The body is also the place where trust and language reveal the complexity of the abused body. The ecclesial and social news have questioned the practices and discourses of the suffering body. Sexual abuse, the abuse of power and conscience, are not marginal realities. From a phenomenological reading, we wonder about the possibility of continuing with life and the role of religious beliefs after having suffered the unspeakable. For this purpose, we have studied different cases and a documentary analysis. We investigate some characteristics of the human being and Christ, as the Messiah who cries and consoles. Christian hope in the face of God-in-the-flesh-crucified can allow suffering bodies to recover. This article assumes the radical difficulty that suffering imposes when thinking, saying, and continuing to live.

Key Words: Body; Abuse; Torture; Territory; Skin; Perversion; Suffering; Hope; Tears.

\section{CÓMO CITAR:}

Achondo, Pedro Pablo. "La (no) metáfora del cuerpo. Cuerpo abusado, cuerpo torturado, cuerpo transfigurado". Theologica Xaveriana (2021): 1-25. https://doi.org/10.11144/javeria$\underline{\text { na.tx71.mccact }}$

\section{ReCONOCIMIENTO}

Agradezco a Eugenio de la Fuente, por su testimonio y confianza. Agradezco a los Grupos de Ayuda Mutua, GAMU, de la Fundación para la Confianza y a la Red de Sobrevivientes de Abuso Sexual Eclesiástico de Chile. 


\section{Introducción}

\section{Oh Dios, no me castigues si digo \\ ¡mi vida fue tan bonita! \\ Somos humanos, nuestros verbos tienen tiempos, \\ No son como el tuyo, \\ Eterno. \\ Adélia Prado}

En este artículo queremos referirnos a uno de los aspectos más crudos de la violencia, la que los seres humanos ejercen unos contra otros; esta violencia inconcebible que deja marcas imborrables en la carne. Para ello intentaremos profundizar en el abuso y la tortura, dos expresiones en las que la agresión se da directamente sobre el cuerpo. Aquí este deja de ser una simple metáfora, una imagen o un juego del lenguaje; él mismo se torna receptáculo de la brutalidad. En el cuerpo, el contenido y el continente se entremezclan, las fronteras se desdibujan y todo el ser sufre.

No cabe duda de que la temática supera con creces las pretensiones de esta reflexión, más aun refiriéndonos al cuerpo; sin embargo, nos parece pertinente volver sobre una dimensión fundamental para el cristianismo y hacerlo precisamente desde su reverso negativo: la apropiación perversa del cuerpo del prójimo.

Hay una expresión acuñada en este camino de los indocumentados: "cuerpomátic". Hace referencia a la carne como una tarjeta de crédito con la que pueden conseguir seguridad en el viaje, un poco de dinero, que no maten a tus compañeros, un viaje más cómodo en el tren. ${ }^{1}$

El "cuerpomátic" de los indocumentados es un horror y constituye la autoentrega del propio ser para poder sobrevivir. Es un cuerpo de sobrevivencia, entre la vida y la muerte. Muchos migrantes intuyen lo que les va a pasar. Aun así, asumen el peligro. Probablemente, el hecho de que la posibilidad de vulneración esté en el horizonte da fuerzas y permite generar una resistencia interior en el momento del vejamen. Pero esto no se condice con la magnitud del horror. Es decir, ni siquiera el hecho de que pueda ocurrir -como en el caso de la violencia y persecución política, en el que la tortura también está entre las atroces posibilidades de la lucha- solapa o disminuye el sufrimiento y el horror de lo padecido.

Hemos visto y oído el horror del abuso y de la tortura. Un caso que ha llamado mucho la atención, tanto a médicos como a creyentes, es el de Frei Tito de Alencar

\footnotetext{
${ }^{1}$ Martínez, Los migrantes que no importan, 84.
} 
Lima $^{2}$, joven religioso dominico del noroeste de Brasil atrapado en tiempos de la dictadura. Producto de la tortura sufrida, Tito decidió acabar con su vida mientras estaba exiliado en el convento dominico de La Tourette, en las cercanías de Lyon. El hecho de haber cometido suicidio provocó un sinnúmero de reflexiones en Francia, Brasil y otras latitudes, y sucedió lo que Tito esperaba. En su declaración, después de un primer intento de suicidio en los calabozos de la Oban (Operación Bandeirantes del Ejército), Frei Tito, de 24 años, escribió:

Solo había una solución: matarme [...] Se trataba de evitar que otros sufrieran la tortura y de denunciar frente a la opinión pública y a la Iglesia lo que ocurría en las cárceles brasileras. Estaba convencido que solo a través del sacrificio de mi propia vida esto sería posible. ${ }^{3}$

Tanto el cuerpo abusado como el cuerpo torturado, a sabiendas de diferencias notables, se sitúa en el horizonte de la extrañeza. De alguna forma, el cuerpo se vuelve un enemigo, un extraño, un canal muchas veces ingobernable de reacciones y padecimientos. Síntomas desconocidos se apropian de una enfermedad que es ajena. Quizás es el fenómeno más cercano a lo que se llama posesión: por parte de un agente externo, en el caso de la tortura, lejano y desconocido; por parte de alguien querido y reconocido, en el caso del abuso, quien,se apropia de nuestra intimidad.

Este agente externo toma posesión del cuerpo de la víctima, hiriéndola. Es como estar en su propia "casa” encerrado, sintiéndose alguien ajeno; o más exactamente, como él mismo en "casa ajena”. Ello provoca delirio, cansancio, fatiga, miedo, ahogo y persecución.

Nunca un abuso o una tortura son iguales. En palabras de las víctimas y en explicaciones profesionales encontramos que nadie reacciona del mismo modo. Es de esperar patrones y desconfianzas, reacciones y tratamientos similares; sin embargo, el abuso y la tortura se configuran respecto del sufriente. Es como si por ser cada cuerpo único e irreproducible, la reacción y el sufrimiento, así como sus eventuales consecuencias, son también únicas e irreproducibles. La experiencia de vulneración sufrida se vuelve, así, incomunicable.

"Las pruebas de la tortura las llevamos en el cuerpo" ${ }^{4}$, dice Frei Tito. Todo pasa por el cuerpo. El cuerpo abusado debe reconfigurarse frente a los demás. Para abordar

\footnotetext{
${ }^{2}$ Duarte-Plon y Meireles, Um homem torturado, nos passos de frei Tito de Alencar. La película de Helvécio Ratton, Bautismo de Sangre (2006, Brasil), inspirada en el libro con el mismo título de frei Betto -que tardó diez ańos en escribir (Batismo de sangue. Rio de Janeiro: Rocco, 2006) - es un verdadero testimonio de lo padecido por Tito y un himno a la libertad.

${ }^{3}$ Ibíd., 184-185.

${ }^{4}$ Ibíd., 186.
} 
más a fondo sobre lo que pasa-por-el-cuerpo, cuando este es vulnerado, debemos hacer uso del lenguaje desde una óptica más poética que meramente racional, es decir, dar cabida al afecto y a la emocionalidad para entender o aproximarse a la piel herida de la persona abusada y torturada.

Sin duda, el abuso es un tipo de tortura. No en vano la tortura muchas veces implica violación y genitalidad. Busca arrebatar la intimidad, lo más propio de la persona: lo secreto, lo privado, lo que solo la confianza y el amor (aunque no siempre se den juntas) permiten mostrar, entregar, ofrecer.

La poética, en cuanto lenguaje afectivo que busca atisbar lo muchas veces indescifrable e inenarrable, nos puede ayudar para descalzarnos delante del cuerpo desnudo y desnudado sin permiso. Se nos sugiere una patética del dolor, una patética del cuerpo y de un cuerpo que en cuanto tal rechaza cualquier metáfora.

En este artículo escucharemos diferentes voces que nos permitirán -esperamoscomprender mejor lo que el cuerpo padece cuando se enfrenta a la perversión. ¿Qué buscamos? Otro lenguaje, otras formas, otra aproximación teológica y dar un contenido más concreto a una batalla que muchas veces parece perdida. La investigación de fuentes secundarias (literatura) y primarias (entrevistas, testimonios y acompañamiento) nos desafía en la fe, pues ella -el hecho radical del amor de Dios- es la que busca decirse, manifestarse y explicitarse como Buena Nueva, no solo a pesar del mal, sino sobre todo cuando estamos sumidos en él.

Metodológicamente presentaremos una reflexión más bien fenomenológica del pathos de la relación abusado/abusador, torturado/torturador, para luego presentar una posible aproximación teológica como insumo al debate y discusión.

\section{El cuerpo, territorio usurpado y conquistado}

Tomen y coman sin miedo, En el límite del amor más tosco Mi pobre cuerpo Es hecho cuerpo de Dios.

Adélia Prado

Afirmar que el cuerpo abusado es un territorio usurpado no es ninguna metáfora. Si somos el cuerpo que poseemos, cuerpo animado y vivificado, este cuerpo es nuestro espacio de pertenencia. Constituye el pequeño territorio -un amplio universo- en donde podemos decidir, desde el que podemos discernir y por medio del cual podemos construir. Nuestro cuerpo es una territorialidad. En este territorio habita lo que somos: subjetividad en construcción, sensaciones contradictorias, aspiraciones sin límites. 
Cuando ocurre un abuso -sexual, de conciencia, de poder o de otro tipo- es nuestro territorio el que se ha visto vulnerado. Cuando un agente externo pretende entrar y conquistar lo que no le pertenece ocurre el abuso, muchas veces mediante engaños, manipulación y traición. No se pretenda creer que un abuso de conciencia no pasa por la carne que somos: reiteramos que en el territorio no hay distinción. Todo pasa por el cuerpo 5 . Incluso en el territorio de Tito, no solo su cuerpo fue masacrado con electricidad, golpes y vejaciones, sino que su psicología, su subjetividad, su "cuerpo orgánico" -de acuerdo con Michel Henry- también y junto a fueron deformados, rompiendo de ese modo la coincidencia entre su ser y su yo.

Podríamos aventurar que en el cuerpo, en cuanto territorialidad usurpada y conquistada, ocurre el paso del "yo soy mi cuerpo" al "yo no soy este cuerpo"; es decir, una total desintegración con la propia carne, una enajenación corporal, un desconocimiento frente a lo que siempre hemos sido.

El cuerpo se transforma en ese campo de batalla contra el usurpador. La persona entra en un espiral agónico contra el colonizador del yo; un colonizador que hace daño, que hace mal, que nos deja malheridos. Según el doctor Jean-Claude Rolland, en uno de los textos más lúcidos respecto de lo sucedido con Tito, dice:

El torturador se inmiscuyó en su víctima, haciendo cuerpo con el suyo en una fusión que no tenía nada de alianza, sino que se trató de una absoluta subyugación. Que la víctima devenga el doble del torturador, su sombra, es lo más impresionante, lo más insoportable posible y nadie, en su entorno, poseía los medios para aprehender y percibir esta metamorfosis. ${ }^{6}$

El territorio es conquistado por el abusador, apropiándose del cuerpo del otro. Esta dinámica perversa se da de manera inconsciente: solo el tiempo va revelando que "este cuerpo ya no es el mío". En el caso del abuso sexual infantil pueden pasar muchos años y no pocas veces la memoria corporal aparece y se nos hace presente debido a otro evento traumático. Es la rememoración traumática la que nos permite acceder a lo que -sabiamente- la memoria nos ocultó. Quizás el propio cuerpo sabe cuándo la persona está en condiciones de abrir esa oscura puerta. El cuerpo necesita en algún momento reconquistar su propio territorio; en caso contrario nos mantenemos ajenos a nosotros mismos, viviendo un exilio corporal que puede terminar en la muerte.

En esa línea, el sujeto perverso, abusador o torturador se apropia del cuerpo ajeno y acrecienta su sensación de poder. Byung-Chul Han, al reflexionar sobre el

\footnotetext{
${ }^{5}$ Para profundizar en el tema, véase la obra de Michel Henry, Filosofía y fenomenología del cuerpo.

${ }^{6}$ Rolland, Soigner, témoigner. Algunos extractos se encuentran en Duarte-Plon y Meireles, Um homem torturado, nos passos de frei Tito de Alencar, 355ss.
} 
poder, afirma que este puede ser comprendido como extensión del cuerpo propio. Es decir, en la medida en que hago mío el cuerpo del otro, mi territorio de acción se amplía, generando dos cosas: una exacerbación del poder (soy más poderoso que los demás) y, alejándose en esto de la postura de Foucault, una exacerbación de la libertad (mi libertad rompe los límites que tenía)7.

Esta dinámica aparece con más fuerza en el caso del abuso, ya que muchas veces no es la violencia la herramienta usada por el abusador, sino el control de la conciencia y por tanto de la libertad del otro. No cabe duda de que poder y sexualidad (placer) están vinculados; de hecho, según Foucault, aquello hace al cuerpo elocuente ${ }^{8}$ y por tanto deseable, atractivo. A más poder, más placer.

El cuerpo, en cuanto territorio, no es solo campo de disputa con el abusador/ torturador, sino geografía de significación con el mundo. Las relaciones humanas están constantemente entrando en el territorio: un saludo, un abrazo, un gesto; compartir espacios, subirse al metro, ir a un recital, sentarse en una iglesia... Somos territorios abiertos o al menos en constante encuentro con otros.

El caso opuesto es al autoencierro, la clausura, opción siempre válida en la medida en que sea una opción. El autoexilio del propio ser inevitablemente provoca una ruptura, una herida y un dolor. La clausura no soluciona el problema y mucho menos sana el cuerpo vulnerado. El mismo caso de Tito es -en este sentido- emblemático: su suicidio acontece en la soledad de un monasterio. Exiliado de su tierra, ahogado por la saudade, y encerrado en su celda, Tito fue completamente absorbido por su torturador. Tito fue clausurado sobre sí mismo.

El cuerpo es habitado por un sinnúmero de gestos, los cuales en sí mismos son ambiguos o poseen la posibilidad de múltiples interpretaciones. El teólogo francés Xavier Lacroix ha profundizado en el tema de los gestos carnales, para llegar a configurarlos en cinco dimensiones constitutivas: (1) los datos inmediatos (sensaciones, localizaciones, formas); (2) el deseo del sujeto, su historia, su memoria; (3) el deseo del otro, su pasado y expectativas; (4) el horizonte común (cotidianidad, fecundidad); y (5) el contexto social (cultura, lenguaje, educación) ${ }^{10}$.

En el cruce de tales aspectos, el cuerpo da sentido al gesto, a sabiendas de que no siempre el cuerpo y la persona coinciden totalmente. Vivimos y nos movemos

7 Han, Sobre el poder, 53-78. Véase también ibíd., 43: "el poder es más espacioso que la violencia” (las cursivas son nuestras).

8 Ibíd., 58.

9 Expresión típicamente brasilera que se refiere a la nostalgia y añoranza a la vez, al sentimiento de recordar con tristeza la tierra, la familia, la cultura, lo propio.

${ }^{10}$ Lacroix, O corpo de carne, as dimensóes ética, estética e espiritual do amor, 79-101. 
en la ambigüedad respecto de nuestro propio cuerpo, en esa espiral de integraciónconocimiento-acogida-desintegración. El lenguaje no es siempre corporal, ni mucho menos las manifestaciones del cuerpo son racionales. Valga como ilustración lo que Lacroix afirma de la penetración, imagen no metafórica del abuso/tortura:

Penetrar es, antes que todo, ser acogido, en la parte más íntima de sí, a través de la parte más íntima del otro. Incluso aquí brota la ambivalencia: ese acto puede ser una violencia, una sustracción, un tomar un lugar; como también puede ser una respuesta, hospitalidad, don. Siempre es, más o menos, una cosa y la otra. Cada uno de los compańeros es acogido y acogedor, rodeado y rodeador, donador y recibidor [...] [Sucede] una introyección mutua donde cada uno está en simpatía, incluso en empatía con lo que experimenta el otro, sintiendo tanto lo que presiente en su pareja como lo que siente en sí mismo... Respecto de la localización de los órganos genitales sucederá a veces una interpretación contradictoria de parte de la conciencia o del inconsciente y elaborado por el imaginario [...] La proximidad entre dos funciones tan contrarias, evacuación de las "cosas malas" y el don de la vida o intercambio amoroso, no puede no provocar una emoción, despertar una oscura angustia, la de la confusión entre dos comportamientos y valorizaciones, dado que el aprendizaje de su diferencia fue una de las tareas más delicadas en la afectividad naciente. La perversión jugará con esa confusión, en la cual está comprometida no solo la imagen del cuerpo y de sí mismo, sino también la estructura de la relación para con el otro. ${ }^{11}$

Una fenomenología de los gestos carnales nos demostrará su ambivalencia inherente y su carácter relacional. Siempre se trata de una relación desde la dinámica del yo-otro-mundo. La relación se ejerce desde, entre y con los tres sujetos implicados y sus dimensiones propias. Por ello, el cuerpo sustraído y poseído por el abusador genera una fractura en la relación de uno consigo, con los otros y con el mundo. La agresión permea todas las relaciones, impidiéndoles su sano y natural desarrollo.

En este sentido y en la mayor parte de los casos la relación con el abusador es muy distinta de la que se establece con el torturador. El cuerpo abusado puede llegar a mantener una relación durante muchos años con su abusador, por ser él miembro de la familia o alguien cercano. De este modo, la relación perversa mezcla el odio con el afecto, el cariño con el rechazo.

En el caso del cuerpo torturado, todo él se ve impregnado de distancia. No existe ningún vínculo afectivo que lo una con su torturador. Esta diferencia puede, incluso, hacer del abuso un trauma mucho más profundo y horrible que la tortura. El odio del cuerpo torturado respecto de su agresor se vuelve su mejor arma de defensa: la total diferenciación y distancia afectiva.

${ }^{11}$ Ibíd., 91-93. 
En el caso del cuerpo abusado, son juegos psicológicos y complejos mecanismos mentales los que permiten la defensa y, en definitiva, la sobrevivencia. El cuerpo - debido al placer y a sentimientos implicados- engaña a la víctima abusada, le hace dudar, culparse, transferir responsabilidades, ahondar en autocuestionamientos. Todo ello solo acrecienta la confusión psicológica y agrava el trauma, provocando un "secuestro de la conciencia" ${ }^{12}$. Es como si el territorio usurpado viviera en permanente estado de alerta, esperando que el tsunami, el terremoto o el bombardeo vuelva a ocurrir, sin aviso y sin posibilidad de prevención, con la única certeza de que volverá a ocurrir, cayendo en el uso "cuerpomátic" de lo que somos.

\section{El cuerpo, piel frágil y membrana permeable}

El cuerpo no posee desvarios, Solo inocencia y belleza, Tanta que Dios nos imita.

Adélia Prado

"Lo más profundo que hay en el hombre es la piel”, decía Paul Valéry ${ }^{13}$. La piel es lo que primero se reconoce en el proceso embrionario. En el principio es la capa aislante, la separación, la protección. Esta capa aislante que es la piel no busca ser un muro infranqueable, sino una membrana, un regulador del afuera y el adentro. Solo así el ser vivo puede formarse y crecer. "No hay insecto sin queratina, ni árbol sin corteza, ni grano sin endocarpio, ni óvulo sin tegumento, ni tallo sin cutícula" ${ }^{14}$.

Para sobrevivir tenemos que cuidar los pliegues, hacernos de una concha o de un refugio al cual volver separados, a recuperar las fuerzas para continuar. La noche y el descanso se transforman en un breve regreso a la matriz. De esa manera somos nuestra piel; somos la piel que habitamos permitiendo que unos entren y otros no; que unos se detengan en las inmediaciones y otros accedan o salgan a voluntad. De eso se encarga la piel. La piel es el filtro del ser: lo que permite el acceso a lo bueno y noble y el rechazo de lo que nos hace mal.

La piel, en nuestra reflexión, está lejos de ser una simple metáfora. Es la piel, literalmente, la que siente y resiente, la que se enferma cuando la membrana ha sido violada, la que reacciona asfixiándose cuando sus poros han sido cercenados por la

\footnotetext{
${ }^{12}$ Expresión usada por la psicóloga Natalia Roa.

${ }^{13}$ Citado por Debray, Elogio de las fronteras, 40; seguimos algunas sugerentes ideas de este libro que recoge una conferencia dictada en Tokio, el 23 de marzo de 2010.

${ }^{14}$ Ibíd., 41.
} 
tortura. Respiramos por la piel: por allí sentimos y nos hacemos sentir. A partir de ella los seres humanos entran en contacto. La piel permite abrir-nos.

En el cuerpo abusado/torturado la piel ha sido robada: ya sea por medio de la violencia de los golpes y sus consecuentes marcas, moretones y magulladuras, o de la nauseabunda caricia y los labios rechazados que ocasionan el pervertido placer, la piel se convierte en vehículo del horror. En la piel llevamos las marcas del trauma. La piel no miente, y ella -en cuanto membrana de protección- carga los indicios del cuerpo maltratado.

La piel del cuerpo abusado manifestará, de alguna manera, lo padecido. Una elocuente consecuencia es la pérdida de voz. La voz consiste en la capacidad del habla, de la comunicación y de la palabra, que son aspectos constitutivos de lo humano. Perder la voz manifiesta el repliegue de lo que nos permitía defendernos del opresor. El agresor nos ha robado la voz, y con ello, la posibilidad de enfrentarlo, increparlo, gritarle.

La víctima se encuentra encerrada en sí misma. El cuerpo abusado, en el rechazo de sí, se transforma definitivamente en nuestra cárcel. La voz es una de las puertas que posee la piel, y al ser cercenada, el cuerpo puede asfixiarse. Eugenio de la Fuente, sacerdote de la diócesis de Santiago y víctima durante 17 años de Fernando Karadima, perdió la voz ${ }^{15}$. Para sacarla escribió un poema llamado "Travesía de un grito" ${ }^{16}$; en él, Eugenio dice:

...emergió el grito/ desde lo más profundo/ del estrangulamiento vital/ en una atmosfera sin oxígeno [...] ¡Cómo gritaba la vida constreńida! [...] Cuando vivía siempre en vilo / en la angustia de complacer/ la caprichosa y exigente voluntad de Dios'/ administrada en dictadura/ por el monstruoso remedo.

Para Eugenio, haber perdido la voz -la autoridad, el respeto, el sentido, la fuerza- significó continuar siendo esclavo de Karadima, ese "monstruoso remedo" de lo sagrado, sin escapatoria alguna.

La relación de esclavitud nos sirve aquí para seguir profundizando en el cuerpo abusado. La esclavitud no es una metáfora. Agamben nos ayuda a comprender el fenómeno de la esclavitud, la antigua y la moderna, en términos de "el uso del cuerpo"17. En la conocida dinámica dialéctica del amo y el esclavo, al parecer, en algún punto, los cuerpos se confunden. Aristóteles decía que "el amo es solo amo del esclavo y no

\footnotetext{
15 Todas las alusiones a Eugenio de la Fuente corresponden a una entrevista-conversación concedida al autor, en Santiago de Chile, el 20 de diciembre de 2018.

${ }^{16}$ Texto inédito (2016) compartido por Eugenio luego de la entrevista.

${ }^{17}$ Agamben, El uso de los cuerpos, Homo sacer, IV, 2.
} 
es parte de este; el esclavo no es solo esclavo del amo, sino que es integralmente parte de este" ${ }^{18}$, al generar una "comunidad de vida".

En lo que respecta al cuerpo abusado/torturado -como iremos dilucidandosucede algo similar, pero deberíamos más bien hablar de una "comunidad de muerte". Agamben, al comentar a Aristóteles, dirá que "poniendo en uso el propio cuerpo, el esclavo es, por ello mismo, usado por el amo, y, usando el cuerpo del esclavo, el amo usa en realidad el propio cuerpo" ${ }^{\prime \prime}$.

Salvaguardando las diferencias, nos aventuramos a decir que el abusador/ torturador se odia a sí mismo. No es solo la perversión la que actúa. Es el odio de sí lo que lo lleva (incrementado por sus actos) a continuar maltratando el cuerpo del otro, como una prolongación de su propio cuerpo. Más allá de los mecanismos psicológicos implicados, nos interesa indagar en esa relación perversa que se genera entre la víctima y el victimario.

Al continuar la lectura que hace Agamben de Aristóteles tenemos que, en la relación de esclavitud, sucede una no-distinción entre el uso del cuerpo y la obra, entre la herramienta y el fruto. El uso del cuerpo del esclavo es su propia obra, el fin. Para demostrar esto pone "el caso de los esclavos de los cuales no había ninguna obra posible, como los niños, cuyo uso coincidía con el deleite que de ellos se obtenía” ${ }^{20}$.

Esos son deleites que no se especifican pero que en el caso del abusador sexual adquieren total sentido. El abuso sexual de un niño o niña se transforma en un acto placentero en sí mismo, para sí mismo, pues el niño no es más que una prolongación del cuerpo del abusador. Dicho de forma brutal, el abuso sexual entendido así es la obra -en cuanto creación, fruto- de autoplacer más elevada para el agresor.

Notemos que la relación amo-esclavo siempre es manifestación de un poder. Nuevamente, más allá de los intercambios y confusiones, la dinámica se da entre alguien fuerte y alguien débil; porque ella exige esa dimensión de autoridad y dominación. Lo mismo en el abusador/torturador: este se sitúa sobre la víctima ejerciendo su poder; por ello el poder, incluso espacialmente, crece en la medida en que más use (abuse, castigue) a la víctima. Mientras más víctimas, mayor será su territorio conquistado. $\mathrm{Al}$ extender su cuerpo propio en el cuerpo abusado/torturado, lo que se acrecienta es su poder. Y, como ya dijimos, su autopercepción -trastocada, sin dudas- de la libertad.

\footnotetext{
${ }^{18}$ Ibíd., 41.

${ }^{19}$ Ibíd., 45.

${ }^{20}$ Ibíd., 49.
} 
Si el esclavo se define como "el hombre sin obra" que permite la realización de la obra del hombre ${ }^{21}$, entonces el cuerpo abusado -que no es un objeto ni tampoco un sujeto plenamente- se transforma en la herramienta para que el abusador realice su obra, que coincide con el abuso mismo. En el caso del cuerpo torturado, la obra del hombre será más bien la destrucción de la herramienta. De cierta manera, el hombre torturado "no es un hombre sin obra", y por ello el agresor debe destruirlo; solo así "su obra" tendrá lugar. Las diferencias nos ayudan a comprender lo propio de cada dinámica y, al mismo tiempo, escudriñar semejanzas en la apropiación sym-bolica (paradójicamente no cabe decir diabólica, aunque sería un mejor adjetivo) del cuerpo del otro.

No deja de ser sugerente la figura del cuerpo-de-poder como perversión; o mejor dicho, la perversión como figura de poder. En la sociedad contemporánea ella aparece con mucha fuerza. Casi de modo paradigmático, las dinámicas sociales, empresariales, políticas y religiosas se equiparan a la personalidad perversa del abusador/torturador fortalecida por el poder. Dicho de otro modo, el ejercicio del poder-dominación muestra su rostro perverso en las dinámicas sociales construidas y mantenidas con base en el aprovechamiento, el engaño, el sometimiento, el acoso, la amenaza y el silenciamiento.

La violencia sexual agrega otro ingrediente al ya referido: lo afectivo, el placer. Sin duda, la tortura ejerce un placer en el torturador, pero es improbable afirmar eso de la persona torturada. Quizás relaciones del tipo sadomasoquistas mezclan la violencia con el placer, pero en ellas, en general, hay consentimiento y aspectos cercanos a lo lúdico. En el cuerpo abusado y en particular abusado sexualmente, puede darse ese tránsito indeterminado ${ }^{22}$ en el cuerpo del otro, propio de las relaciones sadomasoquistas. Agente y paciente se entremezclan modificando las membranas propias. El goce puede ser transferido agudizando la confusión, la vergüenza y el dolor en la piel. Mientras tanto, dicho dolor producido aumenta progresivamente el placer en la persona del abusador/torturador.

De acuerdo con la lectura de Agamben nos parece que en la relación con el cuerpo abusado/torturado debe darse también otro singular aspecto: que la víctima no se transforma en un objeto. La complejidad de esta relación va más allá de una simple objetivación del otro, pues justamente lo que mantiene el vínculo es la imposibilidad de apropiárselo. Eso explica la rabia y violencia en la tortura y la persistencia enfermiza

\footnotetext{
${ }^{21}$ Ibíd., 60.

${ }^{22}$ Ibíd., 81-85.
} 
en el abuso. El cuerpo frágil de la víctima es un inapropiable ${ }^{23}$. El hecho de que no sea posible apropiarse del cuerpo del otro hace que la relación, aunque parezca extraño, permita la empatía.

Más certeramente, es la empatía propia de toda relación -y qué decir en el abuso sexual- la que muestra con todas sus fuerzas la intrusión en una impropiedad, "como si el cuerpo propio" -dice Agamben- "proyectase en cada ocasión una sombra, que en ningún caso puede ser separada de él”, una sombra incontenible e inabordable: como una prolongación de la piel propia escabulléndose todo el tiempo de las garras del agresor.

Lo más propio es el cuerpo en la medida en que permanece y se nos revela como lo absolutamente inapropiable. No sería ilógico pensar que la pérdida de voz de Eugenio consistió en la memoria física de lo inapropiable. De alguna manera, en el cuerpo sobreviviente de Eugenio, como gesto desesperado, se escuchaba un "mi voz nunca la tendrás".

Lo que para Eugenio resultó una defensa -inconsciente e insospechada-, para Tito no fue posible. El diabólico "si no habla lo quebraremos por dentro porque nosotros sabemos hacer las cosas bien, sin dejar marcas visibles" ${ }^{24}$ del capitán Albernaz a los torturadores fue más fuerte que Tito. En efecto, más allá de las marcas en la piel, Tito fue destrozado interiormente. Sin voz, sin fuerzas, sin capacidad de salir, encerrado en sí mismo con el agresor, Tito se transformó en la prolongación del cuerpo del torturador: dos pieles confundidas en una relación nauseabunda en el cuerpo de Tito.

Si la constitución del sujeto tiene que ver con la limitación de la propia piel, con la libre voluntad del cuerpo propio y con la posibilidad de apropiarse de sí mismo ${ }^{25}$, entonces tanto el abusador como el torturador interfieren en esa constitución despedazando la identidad-intimidad de la víctima. Por ello no es extraño que pase mucho tiempo para que la víctima reelabore su propia identidad (en el caso del abuso; y/o que la víctima la pierda totalmente), como en el caso de Tito y de muchas de las víctimas de los Lager.

El abusador del cuerpo se transforma en señor de la intimidad ajena y la relación con lo inapropiable es violentamente usurpada -con o sin éxito-, fracturando lo más propio del cuerpo del otro. En ambos casos, el otro es menos importante que la relación. El abusador no se alimenta de lo inapropiable, sino de la relación con él.

${ }^{23}$ Ibíd., 159-169. Véase el interesante paralelo con la postura de Michel Henry: Nota 33.

${ }^{24}$ Duarte-Plon y Meireles, Um homem torturado, nos passos de frei Tito de Alencar, 184.

${ }^{25}$ Agamben, El uso de los cuerpos, Homo sacer, IV, 2, 179-181. 
Para terminar este apartado quisiéramos indagar brevemente en dos aspectos: uno que tiene que ver con la persona agredida, la vergüenza, y otro con la persona del abusador, lo religioso.

\section{La vergüenza}

En no pocos de los casos, debido a la confusión afectiva con el agresor, el cuerpo abusado siente vergüenza: vergüenza de decir, de contar, de explicar; pero también vergüenza por el hecho de ser descubierto. En el Jardín originario, llamado también Jardín relacional, lo que asusta a los vivientes - macho y hembra- es la vergüenza. Es el hecho de ser descubiertos en su desnudez (Gn 3,10) lo que hace que el ser humano se esconda del Creador. Levinas dirá sobre la vergüenza:

Se refiere a todo lo que se querría ocultar y que no podemos cubrir... lo que aparece en la vergüenza es la imposibilidad radical de escaparnos de nosotros mismos, la presencia irremisible del yo ante sí mismo [...] Es nuestra intimidad, es decir, nuestra presencia ante nosotros mismos la que es vergonzosa. ${ }^{26}$

Lo que no veíamos nos es revelado y es frente a nosotros mismos, en la imposibilidad de ocultarnos, que sentimos vergüenza. El cuerpo abusado se siente ruborizado al ser expuesto en su confusión. Eugenio de la Fuente contaba que sentía justamente lo opuesto a un rubor ${ }^{27}$ : más bien un rubor, pero interior; una vergüenza albergada en la sien; una vergüenza a-moral, que menos tiene de pudor que de frustración: un sentimiento de profunda derrota, una honda desazón para consigo mismo; una vergüenza interior que sin duda cumple la función de alertar al cuerpo abusado.

Ese rubor, ese desear esconderse de sí mismo, radicalmente imposible, y por ello agudamente doloroso, se constituye en la alerta, en el llamado y en la afirmación de que el abuso no debería nunca haber sucedido. De ese modo, la vergüenza, lejos de acercarse a la culpa, es la defensa que posee el cuerpo ante los invasores de esa piel que somos. Y, al mismo tiempo, la vergüenza se torna la memoria corporal -el rubor y su temperatura- de que somos impotentes y frágiles cuerpos necesitados de cuidado. La culpa aparece, no pocas veces impuesta desde fuera (por el/la psicólogo, terapeuta, figura religiosa o la familia, por ejemplo), y deja así su dimensión de defensa y protección, para transformarse en un peso moral y autodestructivo.

\footnotetext{
${ }^{26}$ Levinas, De l'évasion. s/l, Fata Morgana, 1982, 86-87, citado por Agamben, El uso de los cuerpos, Homo sacer, IV, 2, 167.

${ }^{27}$ Eugenio de la Fuente: entrevista con el autor, Santiago, 20 de diciembre de 2018.
} 
Respecto de los niños y la vergüenza, la filósofa y psicoanalista Alice Miller dice:

A diferencia de los adultos que sobreviven a torturas, los niños humillados no explican el mal que les han ocasionado, puesto que la vergüenza se lo impide. Es posible que su memoria consciente consiga incluso olvidar ese martirio y, con toda seguridad, reprimirá el suplicio. Sin embargo, la memoria de su cuerpo ha conservado todos los detalles y su conducta de adulto se encargará después de demostrarlos. ${ }^{28}$

\section{Lo religioso}

El aspecto religioso en la relación abusiva merece un apartado propio. Aquí solo queremos hacer alusión a un fenómeno sin duda extraño: la permanencia del abusador en el rito. ¿Cómo podemos explicar el hecho de que el presbítero-abusador pueda celebrar los sacramentos, en cierta medida, de forma inmutable? Sin querer entrar en aspectos psicológicos, nos centraremos en un aspecto teológico del propio rito cristiano que tiene que ver con el cuerpo.

Según una cierta teología de los sacramentos, proveniente de Santo Tomas de Aquino, entendemos la acción sacramental como algo separado de la persona que la ejecuta: es decir, "el ministro es el instrumento animado de una operación cuyo agente principal es Cristo" ${ }^{29}$, y por ello es innecesario que el ministro tenga fe para que la gracia divina realice lo que se espera y pide. Más aun, el ministro incluso puede tener una intención perversa (bautizar a una mujer con la intención de abusar de ella, explicita Agamben), y ello no interfiere ni le quita validez al sacramento. Esto es posible debido a que el ministro obra ex opere operato (por obra obrada) y no ex opere operante (por obra del operante).

La doctrina del ex opere operato, creada para asegurar la validez del sacramento, puede haber causado una escisión profunda entre el ministro ordenado y lo que él está destinado a realizar. Recordemos la distinción del cuerpo con la obra realizada en el caso del amo y el esclavo. Como la realización del sacramento no depende de su amor, ni de su fe, ni de sus intenciones, estas quedan en segundo lugar respecto de la tarea cotidiana. No afirmamos que sea siempre el caso, pero puede explicar, en alguna medida, esa dicotomía existente entre el cuerpo del ministro-abusador y el acto religioso en vistas del cuerpo de Cristo.

${ }^{28}$ Miller, La madurez de Eva. Una interpretación de la ceguera emocional, 86. Las cursivas son nuestras.

${ }^{29}$ Agamben, El uso de los cuerpos, Homo sacer, IV, 2, 151. 
Esta "tecnología sagrada" ${ }^{30}$ asegura siempre lo que se busca realizar: convertir el pan en cuerpo de Cristo, y con eso genera una distancia infinita con el ministro. Nada de lo que él haga o deje de hacer perjudica la acción sacramental. Esta grave separación entre el cuerpo del ministro y la obra realizada puede haber permitido aberraciones como, por ejemplo, que un presbítero haya abusado de un o una menor en la sacristía y luego se revista para celebrar la eucaristía. Algo así, cercano al culmen de la maldad y perversión, solo se explica (asegurando la conciencia y voluntad del agresor) a partir de esta irremediable distancia entre la persona del celebrante y el acto realizado ex opere operato.

\section{La esperanza del cuerpo abusado/ torturado: el cuerpo transfigurado}

Es inútil el bautismo para el cuerpo. Lo que tiene sus leyes las cumplirá. Los ojos verán a Dios.

Adélia Prado

El camino transitado nos conduce a la pregunta teológica respecto de los cuerpos abusados y torturados: ¿Cómo anunciarles a ellos la Buena Nueva del Dios Amor? Dicho de otro modo, ¿sigue teniendo sentido la esperanza, la fe y el amor cristiano cuando todo se ha derrumbado y nos encontramos encerrados en nuestra piel con eso que nos hace mal?

Para abordar estas cuestiones tornamos la mirada al Cristo agonizante. No es la figura de Cristo Rey ni los triunfalismos baratos los que permitirán una palabra con sentido, sino detenernos en el Siervo golpeado y rechazado, en el único Mesías capaz de acompañar el cuerpo abusado de tantos y tantas: el Cristo torturado, el Cristo violentado, el Hijo de Dios manipulado por el poder, engañado, tratado de la peor manera, rechazado y olvidado. Ese es el Mesías del Dios vivo: el cuerpo crucificado y abandonado entre ladrones.

Proponemos que el cuerpo-territorio y el cuerpo-piel mantienen siempre, $\mathrm{y}$ a pesar de todo, una frontera infranqueable ${ }^{31}$. Permanece una frontera que es imposible violentar. Probablemente y de forma paradójica fue la frontera que llevó a Tito

\footnotetext{
${ }^{30}$ Ibíd., 151.

${ }^{31}$ Según Henry hay una dimensión del cuerpo que siempre se oculta; a esta la denomina cuerpo trascendente objetivo. Este mantendría inaccesible el "infinito de la subjetividad" (Henry, Filosofía y fenomenología del cuerpo, 292).
} 
al suicidio, es decir, su última y única decisión libre. Para matar al agresor tuvo que terminar con su vida. Esa última frontera se nos presenta como una denuncia: el cuerpo jamás puede ser totalmente abusado/torturado. El cuerpo, en algún punto, se enajena de sí mismo para permitirnos seguir con vida.

Desde una perspectiva teológica, ni siquiera la muerte derriba esa frontera. Ni siquiera el asesinato nos quita la piel. Esa piel permanece, herida y transfigurada, tatuada y sanada, en un tiempo nuevo, sin abusos ni torturas, sin irrupciones agresivas ni usurpaciones sin consentimiento. La última frontera permanece como una "esperanza carnal", la afirmación de que nuestros cuerpos no desfallecerán.

Dios creó los cuerpos. Vio que eran buenos, cuerpos para el bien y la bondad, para la donación y la entrega, para la generosidad y la ternura. cuerpos para el cuidado de otros cuerpos; cuerpos de carne, dotados de libertad, capaces de ser cocreadores junto con Dios (Sal 139,13; Sal 28; Sal 51,12). Sabemos que el último encuentro con él tendrá que ver con el cuerpo: si vestimos el cuerpo desnudo, alimentamos el cuerpo hambriento, acogimos el cuerpo errante, visitamos el cuerpo preso (Mt 25), seremos consultados por el buen uso del cuerpo, del nuestro y del otro u otra.

Si de cuerpos fatigados se trata, el del Mesías Jesús es uno de ellos. Si Jesús representa y, más aun, revela lo verdadero que hay en la humanidad del ser humano, el cuerpo fatigado, sediento, cansado es constitutivo de lo humano; un cuerpo humano. Sin embargo, la atrocidad de la cruz, el calvario y las torturas públicas que recibió el cuerpo del Mesías manifiestan todo lo contrario.

Lo divino implicado en lo humano -encarnado-es destrozado por los hermanos, por otros cuerpos llenos de odio, miedo, poder y desprecio. El calvario y la via crucis, en cuanto camino de sufrimiento, se torna así en el paroxismo del cuerpo rechazado y agredido. Si asumimos la feliz frase de Michel de Certeau -"El cristianismo se inaugura con la pérdida de un cuerpo"32) - tendremos que decir que allí donde vuelve a perderse un cuerpo vuelve a comenzar el cristianismo; es decir, los cuerpos abusados/ torturados, los cuerpos desaparecidos y rechazados, los "cuerpomátic" siguen siendo semilla de una esperanza: la de encontrar, reencontrar, buscar y esperar que llegue el cuerpo en otra condición.

Si el cuerpo es el "sacramento primordial", como el primer Juan Pablo II afirmó en $1980^{33}$, entendiendo este sacramento primordial como el signo que transmite de manera visible el misterio invisible de Dios, presente desde siempre en el mundo; y si "el cuerpo, y solo él es capaz de hacer visible lo que es invisible: lo espiritual y lo

\footnotetext{
${ }^{32}$ De Certeau, La Fable mystique. I. XVIe-XVIIe siècle, 88.

${ }^{33}$ Juan Pablo II, “Audiencia general (20 de febrero de 1980)”.
} 
divino" ${ }^{34}$, ¿qué podemos decir del cuerpo destrozado, aniquilado, maltratado? ¿Cómo asumir que el cuerpo abusado es equivalente a destrozar ese signo elocuente de la presencia del Creador en la historia de los seres humanos?

El camino realizado nos ha mostrado la densidad y la negatividad del abuso y la tortura. Hemos visto la batalla narrada desde la piel y el cuerpo como territorio propio. Quisiéramos dar un paso más. Para ello aludimos a dos dimensiones que nos permitirán, quizás, anunciar una Pascua a los cuerpos heridos. Solo a partir de la experiencia de Jesús, Mesías llagado y transfigurado podemos mantener una concepción del cuerpo como promesa y anunciar una esperanza. Estas dimensiones son el tiempo futuro y el llanto silencioso de Dios.

\section{El tiempo futuro}

Hablar del tiempo futuro tampoco es una metáfora. Cuando el cuerpo abusado logra -después de un trabajo de acompañamiento, escucha, indignación y rebeldía-abrirse al otro, abrirse a otros cuerpos que puedan acoger su desnudez y vulnerabilidad, sucede lo necesario: conjugar otros tiempos, hablar con futuro, decía una víctima de abuso sexual ${ }^{35}$, como si ello lo hubiese transformado todo. Solo cuando la víctima logra conjugar el tiempo futuro es que vuelve a integrarse a la corriente de la promesa.

El lenguaje no solo genera realidad: él es en sí mismo una realidad. El cuerpo abusado/torturado no puede quedarse en la memoria estéril del horror, ni cavando su propio pozo de penurias, culpas y vergüenzas. Es necesario integrar el futuro, lo que viene, lo desconocido y sorpresivo: esa dimensión tan propia de lo inexistente. El tiempo futuro, aquí puede ser equiparado al Adviento, en vistas de un nacimiento. El tiempo litúrgico del Adviento es puro futuro, es vivir el presente en la espera de lo que sabemos ocurrirá con total certeza. En otras palabras, consiste en instalarse o abrirse al "tiempo mesiánico". Nuestros cuerpos deben estar abiertos al otro del tiempo, al que se acerca, a la promesa que nos viene a visitar.

Instalarse en el mañana - para el cuerpo herido- corresponde al inicio de un camino. Incorporar la dimensión de un mañana, de un futuro, de un proyecto, independiente de los "cómo" y los "cuándo", es ya dejar de caminar en círculos en torno del propio yo. Es, al menos, desear que ese cuerpo maltratado sea sanado. En este sentido, el cristianismo siempre se conjuga en futuro: es la revelación acontecida y presente avanzando históricamente hacia una promesa inacabada.

\section{${ }^{34}$ Ibíd. 4.}

${ }^{35}$ En grupo de acompañamiento de víctimas (directas o indirectas) de abuso sexual, con el autor. 
Así mismo -y valdría la pena profundizar en ello-, no solo vivimos los tiempos del fin, sino que nuestros cuerpos son cuerpos mesiánicos en el sentido de ser cuerpos orientados y esperados por Dios en el después. Nuestro cuerpo es un cuerpo-para; un cuerpo cargado de futuro, un cuerpo totalmente abierto a otra historia, un cuerpo para la glorificación ${ }^{36}$. No deja de ser sugerente situar los cuerpos vulnerados en esa perspectiva del cuerpo futuro, del cuerpo-para-el-futuro. "En esta perspectiva el cuerpo está en génesis, en venir-a-ser. Son los sucesivos nacimientos del cuerpo del hombre" ${ }^{37}$.

Así, el cuerpo vulnerado, que es un cuerpo que de alguna manera ha muerto y que ha sido destruido, continúa albergando un germen de esperanza y, eventualmente, con la adecuada ayuda, podría reconfigurarse, restaurarse, volver a recibir lo que de suyo se encuentra siempre inacabado. El cuerpo, de ese modo, podrá hablar desde la victoria, desde el tiempo que viene del mañana. En este sentido decimos que la resurrección de los cuerpos comienza en el bautismo y en esa ruta morimos y/o nos matan muchas veces.

\section{El llanto silencioso de Dios}

No queremos aquí profundizar en la dimensión patética de Dios ${ }^{38}$, sino hacer alusión a una hermosa y elocuente imagen: las lágrimas, en vistas sí de una teopatética de los cuerpos heridos. Ante el cuerpo abusado/torturado siempre cabe la pregunta por Dios, el lugar que ocupa, su real posibilidad de intervención y la comprensión de la salvación/defensa del Creador. Bastante se ha dicho también del silencio de Dios ante el grito de horror de Jesús crucificado, intentando homologar ese silencio a la ausencia divina respecto de los abusos y torturas.

Sin duda, una de las respuestas creyentes es el silencio, el silencio acompañante, el silencio de la escucha serena y exigente; pero en este artículo, precisamente, queremos decir algo, aportar con una palabra teológica respecto de quienes "claman desde el abismo". Una arista elocuente es la que refiere a las lágrimas, al llanto, a esa manifestación de la tristeza, la derrota y el desconsuelo. Las lágrimas nos permiten balbucear algo de ese Dios-venido-a-la-carne; no tanto volver sobre las lágrimas de Jesús (Jn 11,35; Lc 19,41; Hb 5,7) sino profundizar en el llanto de Dios en cuanto imagen de su impotencia frente al dolor. En palabras de Catherine Chalier:

\footnotetext{
36 "Glorifiquen a Dios en/con sus cuerpos", dice San Pablo (1Co 6,20), y en el versículo 13: "El cuerpo es para el Señor". Para Lacroix, esta es la verdadera vocación del cuerpo; solo así el cuerpo es verdaderamente cuerpo (Lacroix, O corpo de carne, as dimensóes ética, estética e espiritual do amor, 157).

${ }^{37}$ Ibíd., 161.

${ }^{38}$ Esta dimensión la trabajé en mi libro Desde el abismo clamo a ti Señor. Dios, el sufrimiento y lo que podemos hacer (2017).
} 
[Las lágrimas] portan ese mundo herido o hiriente, ellas desatan por un tiempo sus nudos trágicos y su peso de miseria, no solo de manera simbólica. Como si, derramando sobre el mundo sufriente la ligereza de su agua a penas, por ello, visible, contengan ese asombroso poder, o gracia, de disolver la evidencia rebelde a todos los otros tratamientos..$^{39}$

El silencio de Dios no es tal si él llora, si derrama sus lágrimas tímidamente sobre los cuerpos vulnerados buscando desesperadamente acoger, ayudar, aliviar, curar, acariciar, refrescar, consolar el dolor innombrable de sus criaturas amadas.

La fuerza de las lágrimas no es cuestionada por los sabios judíos. Rabí Isaac llega a afirmar que la liberación de Israel solo dependía de su llanto ${ }^{40}$. La capacidad de llorar por otro es del orden del don; posibilita abrir un espacio para la disidencia, la no conformidad, la rebeldía, delante de uno mismo y delante del otro que sufre. El llorar posee una profunda dimensión pasiva. No todos los llantos son iguales y muchas veces las lágrimas solo caen.

Esa extrema pasividad corresponde a la total desnudez del sufrimiento, es la exposición pura de la tristeza. Ella de ninguna manera deja impasible al Dios que posee entrañas de misericordia. Corresponde al caso de las lágrimas de Raquel. El profeta Jeremías (31,15-17) relata el llanto de la madre por sus hijos. Raquel no busca ser consolada, pero el profeta le dice que sus lágrimas serán acogidas y su llanto escuchado, que el Eterno está allí para recibir a sus hijos.

Para los sabios de Israel, este texto de Jeremías es la clave de lectura para leer las lágrimas de Dios: así como Raquel llora a sus dos hijos, Dios llora por ella y con ella, por todos los hijos de Israel. Es hermoso percibir que esta dinámica de comunión en las lágrimas genera una fuerza solidaria para soportar el mal. La comunidad humano-divina de lágrimas ${ }^{41}$ se transforma en una reparación de lo que ha sido dañado y despedazado.

Al rechazar el consuelo, Raquel testimonia ese aislamiento sordo, propio del sufrimiento desgarrador; y, al mismo tiempo, Jeremías, al afirmar la escucha y acogida de Dios, testimonia su presencia en las lágrimas humanas, en las lágrimas de Raquel. Sin embargo, ¿es suficiente este llorar de Dios y su presencia en las lágrimas del cuerpo abusado para consolar? ¿Podemos hablar de una esperanza real, un abrirse a un futuro, un mantener viva la fe, con la certeza de que Dios nos acompaña con sus lágrimas silenciosas? La misma Catherine Chalier se hace la pregunta: ¿ No será este un esfuerzo

\footnotetext{
${ }^{39}$ Chalier, Traité de larmes, fragilité de Dieu, fragilité de l'âme, 40-41.

${ }^{40}$ Ibíd., 47.

${ }^{41}$ Ibíd., 49.
} 
apologético vano, para salvar a Dios de su indiferencia respecto de la creación? ¿Qué tipo de consuelo es aquel que solo apela al tiempo, a la duración, dado que "nadie puede llorar para siempre"? 42

Sucede que, ante una situación límite para la praxis y el pensamiento humano -como es el sufrimiento y en particular el horror de los cuerpos abusados/torturados-, es necesario recurrir a imágenes, metáforas, antropomorfismos; no para opacar la reflexión, sino para nutrirla de otras características que nos ayuden a abrir la comprensión ante el misterio de Dios, el misterio de lo humano y el misterio del Dios-humano.

Es cierto que una teología implícita anima la imagen de las lágrimas de Dios, pero, según los sabios [judíos], como esta teología no puede tornarse afirmaciones conceptuales sobre Dios sin caer en la idolatría, es bueno siempre volver al lenguaje sensible de las imágenes o de las metáforas para evitar la sordera del saber delante de lo que lo excede. No se trata, evidentemente, de tomar este lenguaje al pie de la letra, sino de buscar, gracias a él y en él, la mejor forma de escuchar la voz en donde la verdad sobrepasa los más altos conceptos forjados por la inteligencia para aproximarse a Dios. ${ }^{43}$

Tanto los libros Sapienciales como los Profetas nos invitan a acercarnos a Dios en la angustia desde las lágrimas, como si el llorar del ser humano fuera una puerta abierta para retomar el camino de la alianza. "No te hagas sordo a mi llanto" (Sal 39,13), "El llanto consume mis ojos”, ¡Clama, pues, al Señor, muralla de Sion capital; que corran a torrentes tus lágrimas!” (Lm 2,11.18).

Este camino se nos vuelve posible gracias al otro que nos sostiene: "No fue un mensajero ni un ángel: él mismo en persona los liberó. Por su amor y su compasión él los rescató: los levantó y los llevó todos los días desde siempre" (Is 63,9); y nos sostiene llorando en esa comunión de lágrimas. Llorar es reencontrar la senda del amor; corresponde al acto humano de abandonarse. Llorar es dejar de defenderse contra el propio sufrimiento. El cuerpo que llora puede dejar atrás, por fin, al abusador.

El llanto silencioso de Dios, en su dinámica encarnatoria, nos lleva a pensar en las lágrimas del Mesías, las lágrimas de Jesús. Catherine Chalier, al aludir a las lágrimas del Mesías -que en su lectura no es necesariamente Jesús de Nazaret-, busca explicitar la dimensión mesiánica del llanto ${ }^{44}$, y no tanto mostrarlo como tentativa de reconfortar a quienes lloran, como en general es leída la bienaventuranza: felices lo que lloran (Mt 5,4). Las lágrimas refieren la perseverancia, el rechazo total del abandono

\footnotetext{
${ }^{42}$ Ibíd., 107 y 121.

${ }^{43}$ Ibíd., 107.

${ }^{44}$ Ibíd., 194ss.
} 
en el mal padecido. Corresponde a mantener la puerta abierta al secreto invisible de donde proviene la vida.

En consonancia con el tiempo futuro, aquí las lágrimas adquieren toda su fuerza. La víctima y los cuerpos vulnerados solo pueden continuar mirando al futuro porque están acompañados del Mesías que mira, llorando, hacia el pasado. El pasado de los cuerpos abusados/torturados es un pasado que no queda atrás, pero allí las lágrimas mesiánicas son capaces de esperar y mantener la esperanza de una reparación y redención de ese tiempo roto. El tiempo es reunificado por este Mesías que llora. Desde la fuerza y resistencia del presente, Mesías y víctima, lloran, uno por la salvación del pasado y el otro por un tiempo nuevo, juntos instalados en la densidad del ahora.

Para Chalier y otros filósofos y sabios judíos, el Mesías habita en el interior de cada persona. De ahí que se pueda decir que "Mesías será el nombre de aquel que espera una sanación del pasado y una salvación para el futuro, el nombre de aquel que ve allá -y solamente allá- la verdadera alegría” ${ }^{45}$. Desde la perspectiva del Mesías Jesús de Nazaret sabemos por la fe que las promesas han sido cumplidas, que el tiempo pasado será redimido y cada lágrima derramada será secada por la mano del Señor.

Si el Mesías llora especialmente por la muerte ${ }^{46}$, por la muerte inocente, por la muerte de los cuerpos maltratados y heridos, entonces el hecho de la resurrección de Jesús consiste justamente en su "reparación". La resurrección es la reparación de la muerte. El Mesías Jesús, al resucitar, manifiesta la victoria final sobre todas las lágrimas, sobre todos los abusos y sobre todas las torturas. El Mesías que llora e implora compasión delante de Dios es Jesús, quien perfuma el Jardín de la resurrección en la mañana de domingo, quien seca las lágrimas de las mujeres y quien anuncia la victoria: ¡No está aquí, ha resucitado! (Mc 16,6).

El hecho de que el cuerpo del Mesías Jesús haya sido vulnerado, maltratado, escupido y azotado (Jn 19,1ss.) no es secundario. Al afirmar que nada tenían que ver con el "plan de Dios" los azotes y las bofetadas, la violencia y odio contra Jesús, deben decirnos algo de nosotros mismos y de las relaciones humanas. Si el Dios-en-la-carne sufrió la tortura de parte de sus semejantes es posible decir, primero, que nadie está exento de sufrir; y segundo, que la violencia entre hermanos y hermanas es posible, es una realidad, sucede.

Queremos insistir en aquello de que el querer de Dios es siempre la plenitud, el gozo, el cariño, el cuidado entre sus hijos e hijas, jamás la violencia. El cuerpo del Mesías crucificado nos transporta a los crucificados de hoy y de todos los tiempos y

\footnotetext{
45 Ibíd., 197.

${ }^{46}$ Ibíd., 201.
} 
culturas; pero la resurrección -como ya dijimos- nos revela otra realidad: el cuerpo del Mesías llagado fue transfigurado, cambiado de figura por Dios. Su cuerpo - de llagas presentes-adquirió un estatus distinto, al transformarse en un cuerpo salvado/sanado.

Es ese cuerpo nuevo el que "está sentado a la derecha del Padre", signo supremo de las promesas mesiánicas. Todos los cuerpos abusados y torturados se sentarán con Jesús -Mesías herido y sanado- junto al Padre amoroso.

\section{Conclusión}

Lo expuesto permite afirmar que tanto el abuso como la tortura merecen ser estudiados y analizados también desde una perspectiva teológica. No caben respuestas fáciles o demasiado ingenuas, ya que el cuerpo no acepta metáforas. Él mismo no es una metáfora, sino la unidad absoluta y concreta de la subjetividad que somos ${ }^{47}$. El maltrato contra los cuerpos atenta o contra la dignidad infinita de cada ser humano, y también contra aquel que deseó ser cuerpo, hacerse cuerpo.

Si el cuerpo es un territorio, puede ser habitado también por Dios. Si el cuerpo es piel que dialoga y se comunica, esa piel puede ser también acariciada por Jesús. La "cultura del cuerpomatic" y del cuerpo como objeto provoca escisiones en la persona humana que no distan mucho de las que generan pervertidos y relaciones enfermas que buscan frustradamente apropiarse del cuerpo del otro. La teología y una necesaria visión unificadora del cuerpo puede permitirnos revalorar esa piel y reconquistar ese territorio, conjugándolos en futuro desde el presente dañado.

El cuerpo herido de la persona abusada/torturada, puede esperar abrirse al otro y retomar la confianza perdida. Esta tarea y arduo trabajo se hace más llevadero en grupos de ayuda ${ }^{48}$, en grupos donde se comparte el horror padecido o presenciado desde la seguridad y la libertad. El grupo se transforma en un cuerpo de seguridad que permite la empatía y suscita la compasión y la escucha serena. Ese nuevo cuerpo o comunidad patética de contención permitirá, con el tiempo, la transformación

\footnotetext{
${ }^{47}$ Henry, Filosofía y fenomenología del cuerpo, 87-157. El filósofo presenta una exhaustiva reflexión y teoría ontológica del cuerpo subjetivo, donde prima la unicidad absoluta y una inmediata percepción con el cuerpo propio. De ahí que -también según Henry- podamos afirmar que el cuerpo y la experiencia que tenemos de él jamás sea una metáfora, ni en el lenguaje ni en la apropiación de la subjetividad que somos. ${ }^{48}$ Como los Grupos de Ayuda Mutua, GAMU, de la Fundación para la Confianza (véase Para la confianza, www.paralaconfianza.org, Chile) y la Red de Sobrevivientes de Abuso Sexual Eclesiástico, quienes de manera elocuente y con pocos recursos se han apoyado para ir haciendo el tránsito de víctimas a sobrevivientes, y luego, a activistas. Este tránsito da sentido a los cuerpos abusados, transformándolos, desde sus heridas, en cuerpos-para-el-cambio, cuerpos de y con futuro (véase Red de Sobrevivientes, https://www.redsobrevivientes.org/).
} 
de los cuerpos heridos, acogerá las lágrimas y hará el trabajo mesiánico de secárselas unos a otros.

Este recorrido "experiencial" y fenomenológico, justamente, buscaba indagar aquellas subjetividades heridas y captar la densidad y profundidad que habita el cuerpo. Solo así, a la escucha atenta de dichos cuerpos, podemos afirmar que estos no mienten, ni mucho menos olvidan. Por lo mismo es imposible creer que el mero apoyo permita la reconfiguración de nuestros cuerpos. El trabajo de "volver a confiar en la piel de otro" ${ }^{49}$ es arduo y difícil: habrá que volver incesantemente a la experiencia de consolación, a una constante relectura de sí y a las promesas de Dios que envía a su Hijo para, entre lágrimas, secar las nuestras y curar nuestros cuerpos.

Esta reflexión busca aportar a una teología crítica y renovada del cuerpo, a la construcción de una necesaria teo-patética en clave ética, que pueda relacionarse respetuosa y adecuadamente con las vidas heridas que no siempre encuentran el consuelo necesario en la fe y sus interpretaciones.

\section{Referencias}

Achondo, Pedro Pablo, Desde el abismo clamo a ti Señor. Dios, el sufrimiento y lo que podemos hacer. Santiago: San Pablo, 2017.

Agamben, Giorgio. El uso de los cuerpos, Homo sacer, IV, 2. Buenos Aires: Adriana Hidalgo Editora, 2018.

Chalier, Catherine. Traité de larmes, fragilité de Dieu, fragilité de l'âme. Paris: Albin Michel, 2008.

De Certeau, Michel. La fable mystique. I. XVIe-XVIIe siècle. Paris: Gallimard, 1987.

Debray, Régis. Elogio de las fronteras. Barcelona: Gedisa, 2016.

Duarte-Plon, Leneide y Clarisse Meireles. Um homem torturado, nos passos de frei Tito de Alencar. Rio de Janeiro: Civilização Brasileira, 2014.

Han, Byung-Chul. Sobre el poder. Barcelona: Herder, 2016.

Henry, Michel. Filosofía y fenomenología del cuerpo. Salamanca: Sígueme, 2007.

${ }^{49}$ Feliz expresión de una víctima indirecta de abuso sexual en grupo de acompañamiento con el autor. 
Juan Pablo II. "Audiencia general (20 de febrero de 1980)". Vatican, https:// w2.vatican.va/content/john-paul-ii/es/audiences/1980/documents/hf jp-ii aud 19800220.html (consultado el 12 de mayo de 2019).

Lacroix, Xavier. O corpo de carne, as dimensóes ética, estética e espiritual do amor. São Paulo: Loyola, 2009.

Martínez, Oscar. Los migrantes que no importan. Oaxaca: Sur Ediciones, 2010.

Miller, Alice. La madurez de Eva. Una interpretación de la ceguera emocional. Madrid: Paidós-Contextos, 2010.

Rolland, Jean-Claude. Soigner, témoigner. Paris: Colloque de la Association Primo Levi, 2011. 